\title{
薬剤投与を契機に間質性肺炎，血管炎を併発した 全身性エリテマトーデスの一例
}

\author{
畠山牧男・溝口義明・隅谷護人・狩野庄吾 \\ 若 山宏*・二/村信 正*・斉藤 建*
}

\section{Systemic lupus erythematosus with interstitial pneumonitis and systemic angiitis}

\author{
Makio Hatakeyama, Yoshiaki Mizoguchi, Morito Sumiya, Shogo Kano, \\ Hiroshi Wakayama*, Nobumasa Ninomura*, Ken Saito* \\ Division of Clinical Immunology, Department of Medicine, and \\ Department of Pathology*, Jichi Medical School.
}

【Summary】

A case of SLE with simultaneous occurrance of interstitial pneumonitis and systemic angiitis after administration of antibiotics and antituberculous drugs is reported.

A 24-year-old woman developed fever and arthralgia during her first pregnancy. On admission in April 1980, she had a mild proteinuria, casturia, hypergammaglobulinemia, positive antinuclear antibodies, high titers of anti.DNA antibody and hypocomplementemia. Circulating immune complex was positive. Renal biopsy revealed mild mesangial proliferation and wire loop lesions in glomeruli. A diagnosis of SLE was made and prednisolone $40 \mathrm{mg}$ daily was effective. In March 1982, fever relapsed when prednisolone was tapered to $10 \mathrm{mg}$ daily. On the second admission, facial erythema was noted. Anti-DNA antibody was $304 \mathrm{U} / \mathrm{m} l$ (normal $10 \mathrm{U} / \mathrm{ml}$ ) $, \mathrm{CH}_{50} 13.7 \mathrm{U} / \mathrm{ml}, \mathrm{CRP} 2+$ and the erythrocyte sedimentation rate $54 \mathrm{~mm}$ per hour. Prednisolone was increased to $30 \mathrm{~m} l$ daily. Fever subsided and titers of anti-DNA antibody decreased. In May 1982, fever, mononeuritis multiplex, dry cough and mild dyspnea developed when she was treated with Cefaclor for a carious tooth. In June, combination therapy with SM, INH and RFP was added because another SLE patient in the same ward was discovered to have pulmonary tuberculosis. Soon after psychosis, tremor and rigidity developed and dyspnea worsened. Blood gas analysis revealed severe hypoxemia and an Xray film of the chest revealed diffuse interstitial infiltration in both lungs. Interstitial pneumonitis, CNS lupus and systemic angiitis were suspected. Pulse therapy with methylprednisolone was started with rapid improvement of hypoxemia and neurological symptoms. Interstitial pneumonitis relapsed again after slight reduction of prednisolone. The patient died after massive gastrointerstinal bleeding and anuria. 
At autopsy, subacute interstitial pneumonitis was observed in both lungs without evidence of cytomegalic inclusion body. Pneumocystis carinii or other opportunistic infections. Generalized angiitis in healing phase with adventitial fibrosis, intimal thickening, mural thrombosis, and ruptured internal elastic laminae was found in small arteries of kidneys, heart, liver, pancreas, spleen, small intestine, adrenal glands and ovaries. However, no evidence of angiitis was found in pulmonary arteries. Ruptured internal elastic laminae were found in the main coronary arteries.

This case represents a rare combination of interstitial pneumonitis and systemic angiitis in SLE, in which antibiotics and antituberculous drugs were implicated as triggering factors.

\author{
Key words : systemic lupus erythematosus, \\ interstitial pneumonitis, \\ systemic angiitis
}

\title{
【概 要】
}

SLE で薬剂投与を契機に多発性単神経炎，間質性肺炎を発症し，剖検で肺と脳を除く全身の臟器に曒痕期の血管炎 を認めた 1 症例を経験した. 症例は 26 歳，女性，24 歳時，多関節炎，発熱，蛋白尿にて発症し，SLE と診断. 2 年後， 抗生刜投与中に発熱, 多発性単神経炎, 乾性咳, 呼吸困難出現. SM, INH, RFP 投与後さらに症状は增悪, 精神・神 経症状も出現した. ステロイド・パルス療法で軽快したが，減量中に再然，2 カ月後死亡した．剖検では肺を除くほ とんどすべての臟器に陳旧性の血管炎を認めた．本例は SLE 患者の血管炎, 間質性肺炎の発症に薬剤が関与し，同 し誘因により発症しても臟器により異なった病態をとる可能性を示した点で重要と考えられた．また血管炎による中 膜の破壊と弹性板の断裂は冠状動脈起始部にまで及んでおり，SLEの血管炎が冠状動脈起始部にまで及びうることを 示した.

\section{I.はじめに}

全身性エリテマトーデス（SLE）に壊死性血管炎や間 質性肺炎が合併することはよく知られている. 今回, SLE の経過中に，抗生鼡，抗結核鼡投与を契機として 血管炎と間質性肺炎を発症したと考えられる 1 例を経験 したので報告する.

\section{II. 症例}

症例 : 26 歳, 女性

主訴 : 発熱

既往歴・家族歴：特記すべきことはない，

現病歴: 昭和 55 年 1 月, 妊娠 4 力月目に多関節炎, 発 熱が出現. 妊娠 8 力月で死産, 産後も下熱せず第 1 回入 院. 入院時現症では発熱以外怯特記すべきことはなかっ たが, 検查所見で, 蛋白尿, 各種円柱尿, $\alpha$-グロプリンの 增加，抗核抗体陽性，抗 DNA 抗体高值，低補体血症を認 め, 血中免疫複合体も $\mathrm{Cl}_{\mathrm{q}}$-binding 法で $32.0 \mu \mathrm{g} / \mathrm{m} l$ と 高值であった。堅生検では系球体にメサンギウム細胞の
びまん性の増生を認め，基底膜の一部はワイヤー・ルー プ様を呈していた. SLE と診断,プレドニジロン（以下 PSL) $40 \mathrm{mg} /$ 日の投与により解熱し，尿所見も改善した. 以後外来で経過観察していたが, PSL $10 \mathrm{mg} /$ 日に減量し た時点で再び発熱，58 年 3 月，第 2 回入院となった.

入院時現症 : 体温 $39.0^{\circ} \mathrm{C}$. 血圧 $132 / 90 \mathrm{mmHg}$. 脈捾 112/分. 整. 呼吸数 12/分. 顔面に蝶形紅斑を認めた。 心，肺，腹部に異常所見はなく，神経学的にも異常はな かった.

入院時検查成績: 貧血なく, 白血球も正常であった. 赤沈 1 時間值は $54 \mathrm{~mm}, \mathrm{CRP} 2+$. 尿蛋白 $0.4 \mathrm{~g} /$ 日で, 円柱尿は認めなかった. 朋機能, 堅機能は正常. 血清学 的検查では抗核抗体陽性で抗 DNA 抗体は $304 \mathrm{U} / \mathrm{m} l$ と 著増, $\mathrm{CH}_{53}, \mathrm{C}_{3}, \mathrm{C}_{4}$ ，はいずれも低下していた. $\mathrm{HB}$ 抗原， HB 抗体はいずれも陰性であった. 胸部X線像怔正常で あった。，心電図では $\mathrm{V}_{1}$ で陰性 T波を認めた。

臨床経過 (図 1)：PSL $30 \mathrm{mg} /$ 日に增量 し, 解熱し た. 5 月中旬, 5菌の抜歯のための前処置としてセクフ フクロルを投与したところ，発熱，手足の多発性単神経 


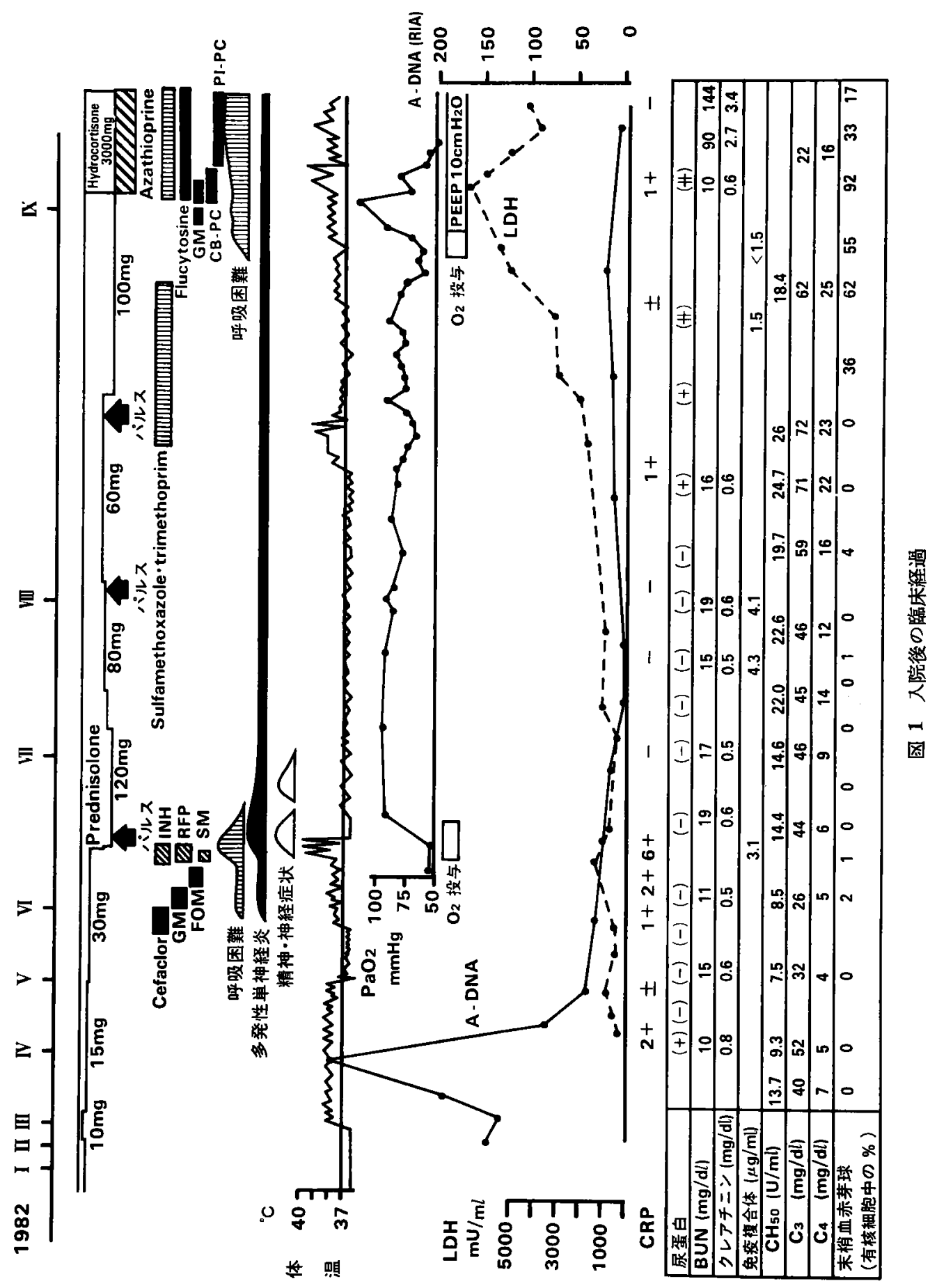

炎，乾性の咳，軽度の呼吸困難が出現. たまたま同室患 者が結核を発症し，結核の可能性も否定できないため, 硫酸ストレプトマイシン (SM), イソニアジド (INH), リフォンピシン (RFP) の投与を開始した. しかし体温
はさらに上昇し, CRP \& 6+ となり, 多発性単神経炎 の部位も拉大した，背部で捻䇣音を㯖取，胸部 X線像で も網状影の増强をみ, 動脈血ガス分析では $\mathrm{PaO}_{2}$ は $60.6 \mathrm{mmHg}$ と低下していた。 さらに幻聴，筋強剛，振 
戦，深部反射の左右不対称などの精神・神経症状も出現 した. しかし薬剤投与時にショックはみられず, DIC (disseminated intravascular coagulation) の所見も認 めなかった. 間質性肺炎, 血管炎, 中枢神経系ループス の併発と考え PSL $120 \mathrm{mg}$ に増量し，メチルプレド= ソ゚ロンによるパルス療法も行ったところ，いずれの症状 も急速に改善した.

PSL を漸城し, $60 \mathrm{mg} /$ 日にしたころより再び $\mathrm{PaO}_{2}$ が 徐々に低下した. Pneumocystis Carinii 肺炎合併の可能 性を考え，スルファメトキサジール・トリメトプリム （ST 合剂）を加えたが勃果なく，再度パルス療法を行 い，低酸素血症は改善した. しかし8月末よりまた $\mathrm{PaO}_{2}$ が低下, 胸部 X線上も網状影は增強した（図 2). 持続陽圧呼吸を行い肺所見は一時的に改善したが，9月 再び $\mathrm{PaO}_{2}$ が低下, 下血, ショック, 乏尿も加わり死亡 した.

検查成績では入院時高値であった抗 DNA 抗体は PSL $30 \mathrm{mg}$ /日の投与で急速に低下し, 以後再び上昇は みられなかった. 多発性単神経炎, 間質性肺炎発現時に 好酸球增加や IgE の増加はみられなかったが血清 GOT, GPT, は $100 \mathrm{U} / \mathrm{m} l$ 台に軽度上昇した. 腎機能の 低下は死亡直前むで認められなかった. 一方血清 LDH 值注多発性単神経炎, 間質性肺炎発現 時 $k 1,000 \mathrm{U} / \mathrm{m} l$ まで上昇，その後一時低下したが, PSL の減量とともに 再び上昇, 死亡前には $5,000 \mathrm{U} / \mathrm{m} l$ 台まで上㫒した. ア イソザイムでは $\mathrm{LDH}_{2,3}$ の増加がみられた。 また間質性 肺炎の発現時，および再然の時期に一致して末梢血中に 赤芽球の著明な出現をみ, leucoerythroblastosis の所見
を呈した．9月はじめには末梢血中に巨核球も出現し た.

剖検所見：肺は硬く，組織学的には肺胞管壁に沿う硝 子膜形成と, 炎症性細胞浸潤によるびまん性肺胞壁肥厚 を認め，亜急性間翼性肺炎と湷断した（図 3). Pneumocystis Carinii や巨細胞封入体は認々られなかった. 間 質性肺炎以外の主要な所見は, 中膜の破壊と弹性板の断 裂を伴う陳旧化した血管炎を，腎，心，肝，脾，膵，小 腸, 副腎, 卵巣の臟器内小動脈に認めたことである. 腎

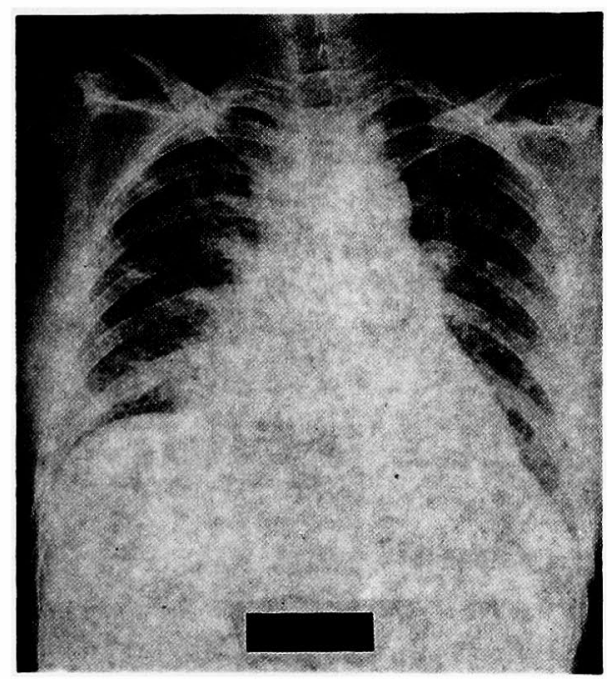

図 2 : 胸部 $X$ 線像 (昭和 57 年 8 月)

両肺野にはびまん性に網状影の増強を認 め, 右横隔膜の挙上を認める

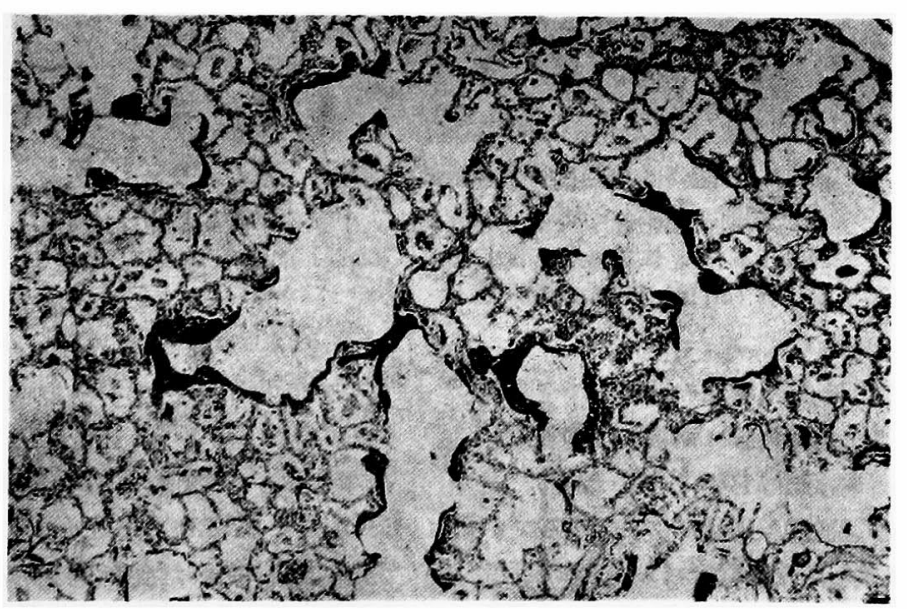

図 $3:$ 肺でみられた間質性肺炎

肺胞壁の肥厚と硝子膜形成の認められる典型的間質性肺炎である

(30 倍, Azan-Mallory 染色) 


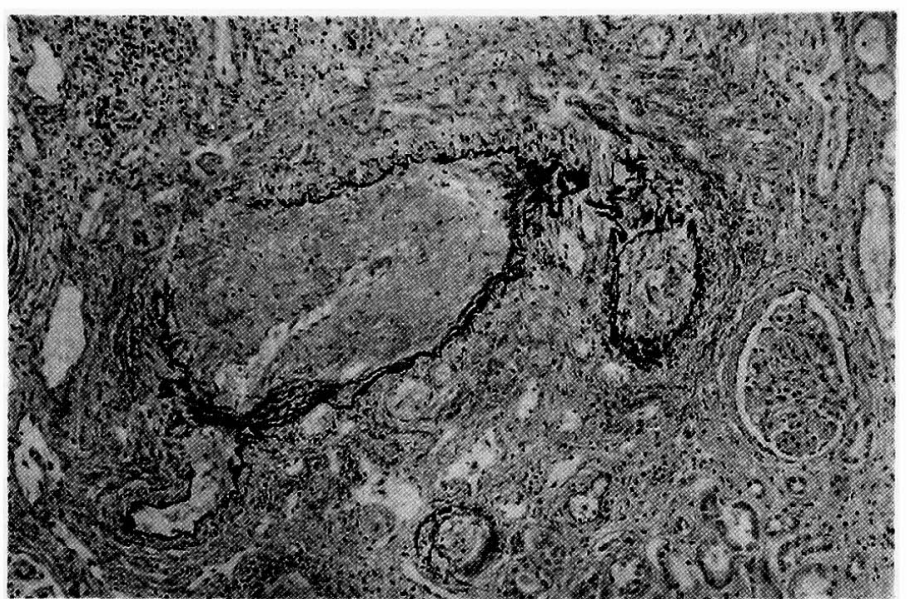

図 4 腎動脈に琶められた陳旧性血管炎

左下方の腎小莱間動脈起始部は中央で小動脈瘤状に拡張し, 左上 方で内弾性板は断裂し，中膜は完全に消失している.この部拉よび 右中央のこれに続く動脈内膜は著明に肥厚しているが，弾性線維の 新生はない. 炎症性細胞浸潤はほとんどなく, 㓔痕化した動脈炎で あるが，それほど古いものではない（70倍, EVG 染色)

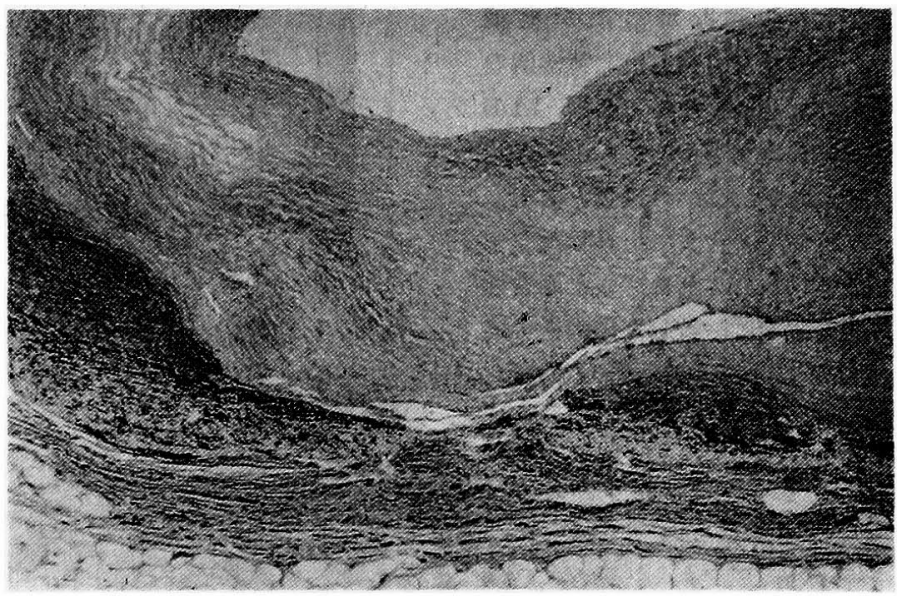

図 5 : 右冠状動脈起始部に認めた中膜の消失

右冠状動脈起始部中央部で弾性線維, 中膜の平滑筋細胞はほとん ど消失し，そこに線維化が認められ，内膜は著明に線維性に肥厚し ている.（40倍, EVG 染色)

動脈では弓状動脈，小葉間動脈に中膜の破壊を伴う陳旧 性血管炎を認め, 一部は小動脈瘤状に拡張し, 器質化さ れた血栓による内膜の著明な肥厚を認めた（図4). 冠 状動脈では中膜の破壊は冠状動脈起始部にまで及んでい た（図 5).肺動脈には明らかな血管炎はなかった，脳 に明らかな血管炎はなかったが，小脳，脳幹部には小数 のク゚リア結節が認められた. 采球体病変は腎生検時より 進行していた.
III. 考 案

本症例は，ARA の 1982 年改訂 SLE 診断基準で 6 項 目を満足する SLE である.

剖検で認められた血管炎はフィブリノイド変性や細胞 浸潤はみられず, 弾性板の断裂，中膜の破壊と線維化， 内膜の線維性肥厚はあるが, 弾性線維の新生はいまだみ られず, Arkin ${ }^{1)}$ らのいう壊死性血管炎のIII期とIV期の 
中間に位置する所見であった，塄死性血管炎の局所病変 はステロイド治療により急速に治瘾，瘵痕化に向かうと され2)，本例も 2 力月閒にわたる大量ステロイド療法が 病像を修飾した可能性が強い，本例においても認められ た血管炎はその病理像において多発性結節性動脈炎の廄 痕期の血管炎と区別し難いが，原疾患が SLE である と，最近，多発性結節性動脈炎の病因との関連で注目さ れている HB 抗原, HB 抗体も陰性であることより,SLE に合併する血管炎と考えるべきと思われる．血管炎の部 位は臟器内の中・小動脈レベルを主としていたが，冠状 動脈では起始部にまで弾性板の断裂を伴う中膜の破壊が 認められた. 一般に SLE でみられる壊死性血管炎は臟 器内の中・小動脈沉主にみられ，大動脈やこれより直接 分枝する動脈にみられること注ほとんどないといわれ

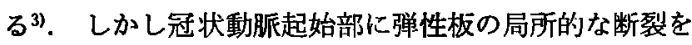
認めた報告むありり，まれには SLE で血管炎が冠状動 脈起始部にまで及ぶことを示している。

肺では亜急性間質性肺炎の所見を認めたが，日和見感 染を思わせる所見はなく，また肺動脈には大循環系にみ られたような血管炎はみられなかった。

本例で剖検時認められた間質性肺炎, 血管炎はいっ發 症したと考えるべきであるうか，間質性肺炎を思わせる 幹性咳，呼吸困難，および血管炎の存在を疑放せる多発 性単神経炎, 発熱は抗生剂セファクロルの投与とともに 発現し, さらに SM, INH, REP の投与後に急速に増悪 している. この時期に薬剤投与を契機に間質性肺炎と, 新たな血管病変が出現したと推定される。

菓郕が間質性肺炎や血管炎をおこすことはよく知られ ている. 本例で発症一の関与が考えられるセファクロル では報告はないが，同じセファロスポリン系のセファレ キシンやセファロチンナトリウムによる薬剤性肺臟炎の 報告があり，INHでも報告されている。一方 SM，INH は薬剤誘起性 SLE を惹起することが知られ，RFP はス テロイド郕の半堿期を短縮することにより，宽解中のネ フローゼ症候群や SLE に再燃をもたらすことが報告さ れている6,7).

したがって，本例では，萖郕自体が血管炎や肺兴炎を おこしたか，あるいはこれらの薬㓝が SLE の再然をる たらし血管炎や肺葴炎を誘発したと考えるべきかいずれ とも断定し難い：しかし，一般に楽剤過敏症でみられる 好酸球の増加などみられず，また本例の血管炎は臓器 内の中・小動脈を主体として拉り，主として細小血管を 場とする過敏性血管炎の型をとる薬剤による血管炎防よ りる，SLE による血管炎を発症したと考える力が妥当と 思われる.ただし多発性単神経炎，閒質性肺炎発症時に
抗 DNA 抗体の再上昇はみら机ず，抗 DNA 抗体が高值 をとる型での SLE の再燃ではなかったことを示してい る.

共通の誘因による発症と考えられるのに，肺では閒質 性肺炎を生じたが血管炎はみられず，一方，大循環系動 脈では広沉に血管炎がみられた。 またすでに存在したル ープス腎炎住，多発性単神経炎，間質性肺炎発症時に臨 床的に増恶を認めなかった．同じように免疫複合体の関 与が考えられている発症機序によっても臟器により異な った病態が発生しうることを示している．細田引らは SLEに扣いて大循環采に分布寸る壊死性血管炎は肺 動 脈系を侵すことが少ないと述べ，長沢ら9)はループス腎 炎々壊死性血管炎では関与する免疫複合体の大きさが異 なるとしている，われわれの症例もループス腎炎発症時 は $\mathrm{C}_{1 \mathrm{Q}}$-binding 法で免疫複合体は高值であったが, 多 発性単神経炎，間犋性肺炎発症時は軽度の増加にとどま っていた.

ほぼ同時期に発症したと考えられ，ステロイド・パル 不療法にともに良好に反応しながら，間質性肺炎のみが ステロイド剤减量とともに再燃した，剖検でも血管炎は すでに癜痕・治瘾化していたが, 間質性肺炎は線維化傾 向はみられず亜急性の状態にとどまっていた. Oku ら はステロイド減量中に発症したループス肺炎で，肺生検 でも感染の所見を認めず，ステロイド増量により治傯し た例を報告している，間質性肺炎は血管炎に比ベステロ イド減量中に再然しやすいことが考えられ，SLEによる 間質性肺炎のステロイド治療上注意すべきであるう。

検查所見と臨床经過との関連において，間質性肺炎の 経過ともっともよい相関を示したのは血清 $\mathrm{LDH}$ ，とく に $\mathrm{LDH}_{2,3}$ の增加であった. これは原因不明の間質性肺 炎ではすでに知られているが11)，SLE でみられる間質性 肺炎においても血清 LDH はよい指標となりうると考え られた.

興味あることは，間質性胢炎の発症時，再燃時に一致 して末梢血中に赤芽球の出現をみ， leucoerythroblastosis の像を示したことである. 血液学的に注溶血の所見 はなく，骨髄にとくに異常はみられなかった. leucoerythroblastosis は骨䯣楾維症や癌の骨䯣転移のほか，膠 原病，慣性肺疾患，薬郕中毒などでもみられるとい

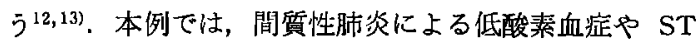
合戍などの薬凨によるとも考えられるが，経過が必ずし も一致せず，アザチオプリン投与後に改善傾问を認めて いることより，何らかの免疫学的機序が関与している可 能性も否定できない，

本例は, SLE の血管炎を生前に診断することの困難さ 
を示した，血管炎でみられる発熱，白血球增加，CRP 强陽性は感染症でもみられる. 本症例でも PSL $30 \mathrm{mg} /$ 日の投与にかかわらず発熱をきたしたため，感染を考え た. SLE で中等量のステロイド剤を使用しながらも発熱 がみられる場合，感染症のほかに血管炎の可能性も考え られ，多発性単神経炎などの血管炎の症状の有無に注意 すべきと考えられた。

\section{IV.おわりに}

SLE の経過中に抗生剤，抗結核侴の投与を契 機に血

$$
\text { 文 }
$$

1) Arkin, A. : clinical and pathological study of periarteritis nodosa. A report of five cases, one histologically healed. Am. J. Pathol., 6 : 404431, 1930.

2）細田泰弘：血管炎診断のための生検，Medicina， 16 : 2111-2114, 1971.

3) Hosoda, Y. : Angitis in SLE. A clinicopathological study. リウマチ, $20: 171,1980$.

4）柴田整一，他：経過の長短による SLE 血管炎の 形態像の分析一 2 剖検例の検索，厚生 省特 定疾 患，系統的血管病変に関する調查研究班，1981 年度報告書, p 387-392.

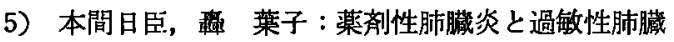
炎. 日本臨床， $41: 519-529,1983$.

6) Hendrickse, W., Mickiernan, J. : Rifampicininduced non-responsiveness to corticosteroid treatment in nephrotic syndrome. Br. Med. J., I (6159) : 306, 1979.

7) 吉井昭夫 - 他 : RFP の steroid catabolism 元進 作用により steroid の大量投与を余儀なくされた SLE の一例. 日本内科学会第 325 回関東地方会 発表.

8) Mullick, F.G., et al. : Drug related vasculilis
管炎，間質性肺炎をほぼ同時期に発症したと考えられる 症例を報告した。

剖検にて，廐痕化した壊死性血管炎が全身各归器に認 められたが，肺では血管炎は認められず，亜急性閒質性 肺炎が認められた。

冠状動脈起始部に中膜の破壊と内弾性板の断 裂を認 め，血管炎は冠状動脈起始部にまで及んだと考えられ た.

献

Clinicopathologic correlations in 30 patients. Human pathology, $10: 313-325,1979$.

9）長沢俊彦，吉田雅治：RA，MRA， PSS, SLE 症例 の血中免疫複合体 (CIC) サイズの分析. 厚生省 特定疾患，系統的血管病変に関する調查研究斑， 1981 年度報告書, p 319-324.

10) Oku, H., et al. : Fuluminant pneumonitis developed during the middledose corticosteroid therapy in systemic lupus erythematosus. Osaka City Medical Journal, 2 : 145-149, 1980.

11）岡野 弘・他：原因不明のびまん性間質性肺炎に おける血清 LDH，LDH Isozyme および血清 IgA 值について。 日胸疾会誌，16：705-710，1978.

12) Weick, J.K., Hagedorn, A.B., Linman, J.W.: Leucoerythroblastosis : Diagnostic and prognostic significance.

13) Wintrobe, M.M. : Neoplastic disorders of the haematopoietic system: The leukemia, polycythemia vera, and myelofibrosis; chap 66 . Clinical Hematology (Wintrode, M.M. ed. 8th ed.), Lea \& Febiger, Philadelphia. 1981, p 1615-1630. 